\begin{tabular}{|l|l|l||}
\hline \multicolumn{2}{|c|}{ PublisherInfo } \\
\hline \hline PublisherName & $:$ & BioMed Central \\
\hline \hline PublisherLocation & $:$ & London \\
\hline \hline PublisherImprintName & $:$ & BioMed Central \\
\hline \hline
\end{tabular}

\title{
Radiation resistance genes discovered
}

\begin{tabular}{|l|l|l||}
\hline \multicolumn{2}{|c|}{ ArticleInfo } \\
\hline \hline ArticleID & $:$ & 4265 \\
\hline \hline ArticleDOI & $:$ & $10.1186 /$ gb-spotlight-20011129-01 \\
\hline \hline ArticleCitationID & $:$ & spotlight-20011129-01 \\
\hline \hline ArticleSequenceNumber & $:$ & 336 \\
\hline \hline ArticleCategory & $:$ & Research news \\
\hline ArticleFirstPage & $:$ & 1 \\
\hline \hline ArticleLastPage & $:$ & 3 \\
\hline \hline & & RegistrationDate : 2001-11-29 \\
ArticleHistory & $:$ & OnlineDate $\quad$ 2001-11-29 \\
\hline \hline ArticleCopyright & $:$ & BioMed Central Ltd2001 \\
\hline \hline ArticleGrants & $:$ & \\
\hline \hline ArticleContext & $:$ & 130592211 \\
\hline \hline
\end{tabular}


The genetic apparatus underlying the susceptibility of a cell to ionizing radiation has become clearer, with the discovery of 107 new genes associated with this cellular response mechanism. This has widereaching implications for identifying strategies to protect against the effects of ionizing radiation and designing novel chemotherapeutic agents.

A screen of mutant yeast cells identified 107 new genes that affect sensitivity to ionizing radiation. This discovery more than triples the number of genetic loci believed to play a role in DNA repair and the related functions that are induced by radiation damage. More than half of these new yeast genes appear to have a homolog in the human gene pool, and 17 of those have been linked to various cancers.

These genes may determine how well cells are able to survive exposure to radiation, and may even help predict sensitivity to other DNA-damaging agents, such as anti-cancer drugs. It is the ability to target these genes during the drug discovery process that could lead to the development of more effective chemotherapeutics.

An important and unexpected finding of this study is that many of the newly identified radiationresistance genes fall into functional groups not previously linked to genetic repair mechanisms. Many of them affect cell replication, recombination, and cell-cycle checkpoint functions - traditional pathways linked to the repair of nicks and breaks in the DNA. But others appear to be involved in a variety of cellular activities including chromatin remodeling, chromosome segregation, nuclear pore formation, transcription, Golgi/vacuolar activities, ubiquitin-mediated protein degradation, cytokinesis, mitochondrial activity and cell-wall maintenance.

"I only expected to find a few more [genes] and expected them to be related to a DNA metabolic effect," said Michael Resnick, from the Laboratory of Genetics at the National Institute of Environmental Health Sciences, a senior author of the study. "The discovery that genes involved in transcription and protein synthesis play a role in radiation sensitivity was quite a surprise", continued Resnick.

Also surprising was the observation that mutations in genes that make nuclear pore proteins were essential for survival in radiation-damaged yeast. These proteins define the structure of nuclear pores, which control the movement of proteins in and out of the nucleus. Resnick speculated that, in response to radiation damage, cells may send out a cell-wide 'SOS' call, mobilizing an army of previously unknown repair molecules that must enter the nucleus. These molecules could serve as targets for clinical interventions aimed at enhancing or disrupting DNA repair activity.

Prior to this study, only 23 radiation-sensitive yeast mutants had been identified. Resnick and colleagues screened 3670 non-essential Saccharomyces cerevisiae genes (two-thirds of the total gene number) and found 107 new genes that, when mutated, increased sensitivity to ionizing radiation. Unlike previous screens, which measured changes in gene expression following irradiation, this study evaluated gene function, by determining which mutant strains could no longer grow in culture and form colonies.

Bennett et al. then showed that among the 107 gamma-ray-sensitive deletion mutants, only about half were also sensitive to ultraviolet radiation. They were quite surprised to find that nearly $25 \%$ of the 
radiation-sensitive mutants were resistant to the anti-cancer drug bleomycin, which causes breaks in the DNA similar to those caused by radiation. The authors speculate that there must be differences in the spectrum of damage and the mechanisms of repair in response to gamma irradiation and bleomycin. It is possible that these differences could be exploited to enhance the effectiveness of cancer therapy while protecting normal cells from damage.

This study demonstrates the importance of being able to link changes in gene function in response to an environmental stimulus to the ups and downs of gene expression measured in microarray-based assays. Functional assays help define "the genetics of the response," said Resnick. "We think this opens the way to many more targets."

\section{References}

1. Radiation resistance Genome Biology 22 November 2001, [http:/genomebiology.com/spotlights/ articles/SpotlightCompiler.asp?xml=20011122-1.xml\&Status=Archive]

2. National Institute of Environmental Health Sciences, [http://www.niehs.nih.gov]

3. Bennett CB, Lewis LK, Karthikeyan G, Lobachev KS, Jin YH, Sterling JF, Snipe JR, Resnick MA: Genes required for ionizing radiation resistance in yeast. Nat Genet 2001, DOI: 10.1038/ng778., [http://www.nature.com/ng/]

4. Saccharomyces genome deletion project, [http://www-sequence.stanford.edu/group/ yeast_deletion_project/deletions3.html] 